\title{
Development and maturation of the lung in fetuses of Galea spixii and expression of markers
}

\author{
Desenvolvimento e maturação do pulmão em fetos de \\ Galea spixii e expressão de marcadores
}

\author{
Phelipe Oliveira Favaron ${ }^{\mathrm{I}^{*}}$ Moacir Franco de Oliveira ${ }^{\mathrm{II}}$ Jéssica Borghesi $^{\mathrm{I}}$ \\ Adriana Raquel de Almeida AnunciaçãoI Maria Angelica Miglino ${ }^{I}$
}

\section{ABSTRACT}

The aim of this research was to study the development of the lung in Galea spixii, by gross anatomy, histological analysis and immunohistochemical techniques. Totally, 8 fetuses were used and allocated into three groups of age: Group I (33-35 days), Group II (38-40 days), and Group III (43-45 days) with given crown-rump - CR lenghts. According to the gross morphology, there were no differences in relation to the lung morphology among groups. In relation to lung maturation, the Group I showed early formation of the bronchi and bronchioles, which were richly surrounded by mesenchyme and small blood vessels, typical features of the pseudoglandular stage. Individuals from Group II showed higher amounts of tubular formations in the lung parenchyma and reduced mesenchyme, reaching the canalicular stage. The lung from individuals of the Group III was completely formed, reaching the alveolar phase. In the immunohistochemical analysis, the lung of individuals from both Groups I and II were positive for Pcna, Oct-4, and VEGF. In contrast, there was not labbeling on samples from Group III. Thus, the G. spixii lung anatomy resembles the agouti (Dasyprocta sp.) lung, in relation to the number of lobes and fissures. In regard to the lung development, $\boldsymbol{G}$. spixii showed more similarity with the human fetal lung, since both are born in the stage of the alveolar phase, different to other rodent species.

Key words: respiratory system, alveoli, morphology, rodent, experimental model.

\section{RESUMO}

Buscou-se estudar o desenvolvimento do pulmão do preá (Galea spixii) com ênfase nas características macroscópicas, histológicas e imunohistoquimicas, bem como acompanhar a proliferação celular. Para tanto, foram utilizados 8 fetos, os quais, de acordo com o tamanho (crown-rump - CR), foram divididos em 3 grupos: Grupo I (33-35 dias), Grupo II (38-40 dias) e Grupo III (43-45 dias). Macroscopicamente, não houve diferenças quanto à morfologia do pulmão entre os grupos. Em relação à maturação pulmonar, no grupo I, observou-se o início da formação dos brônquios e bronquíolos, os quais estavam rodeados por grande quantidade de mesênquima e vasos sanguíneos de pequeno calibre, caracterizando o estágio pseudoglandular. Os indivíduos do Grupo II apresentaram maior quantidade de formações tubulares no parênquima pulmonar, assim como redução da quantidade de mesênquima, atingindo, dessa forma, a fase canalicular. No Grupo III, os pulmões apresentaram-se completamente formados, atingindo a fase alveolar. Nas análises de imunohistoquimica, os pulmões dos indivíduos dos Grupos I e II apresentaram marcação para Pcna, Oct-4 e VEGF. Por outro lado, não houve marcação no Grupo III. A anatomia do pulmão do preá se assemelha ao pulmão da cutia (Dasyprocta sp.) quanto ao número de lobos e fissuras. No que se refere ao desenvolvimento pulmonar, o pulmão do preá apresentou maior similaridade com o pulmão de fetos humanos, visto que ambos, ao nascer, encontram-se na fase alveolar contrário a outras espécies de roedores.

Palavras-chave: sistema respiratório, alvéolos, morfologia, roedor, modelo experimental.

\section{INTRODUCTION}

The lower respiratory tract starts its development from an endoderm epithelial bud, from the primitive gut, as a medial laryngotracheal groove in the early larynx floor, which deepens to form the respiratory diverticulum (MOORE \& PERSAUD, 2008).

Lung maturation is divided into four periods: (a) pseudoglandular, (b) canalicular (c) terminal sac, and (d) alveolar phases. Alveolar

'Departamento de Cirurgia, Faculdade de Medicina Veterinária e Zootecnia, Universidade de São Paulo (USP), Av. Prof. Dr. Orlando Marques de Paiva, 87, Cidade Universitária, 05508-270, São Paulo, SP, Brasil. E-mail: phelipe.favaron@yahoo.com.br. "Corresponding author.

"Departamento de Ciência Animal, Universidade Federal Rural do Semi-Árido (UFERSA), Mossoró, RN, Brasil. 
epithelial type II cells are responsible for the synthesis of pulmonary surfactante, a lipoprotein complex that contains about $30 \%$ protein and $70 \%$ lipids. The surfactant develops several important functions, but the most obvious is to reduce the surface tension of the alveoli, without which they would tend to collapse during exhalation (JUNQUEIRA \& CARNEIRO, 2006). Thus, the alveolar epithelium can be considered the active metabolic unit of the lung (REECE, 2006).

The need of experimental models that may reproduce human lung diseases has led researchers to study the development of the respiratory system in different species as in murines (METZGER et al., 2008), suine (BALAZS et al., 1994), rabbit (BARONE, 1997), and non-human primates (MCCULLOUGH et al., 1978). Especially rodents have contributed significantly as experimental models for understanding various diseases (CABRAL, 2013).

The cavy (Galea spixii) shows interesting characteristics related to reproduction and embryonic development, such as a long gestation period of around 48 days (OLIVEIRA et al., 2012) and reduced time of growth (ROBERTS \& PERRY, 1974) when compared to other rodents. In this way, it was studied the development and maturation of the lung in the cavy in order to describe the macroscopic and histological characteristics, including cell proliferation and the presence of pluripotent cells during fetal life.

\section{MATERIALS AND METHODS}

Eight cavy fetuses at different gestational ages obtained from Cemas - Center of Multiplication of Wild Animals, at the Universidade Federal Rural do Semi-Árido (UFERSA), Mossoró-RN, Brazil were used. Fetuses were already fixed in formalin $10 \%$ or buffered glutaraldehyde $2.5 \%$ and were used in other previous studies related to placentation (OLIVEIRA et al., 2012). The research was registered with the IBAMA (Protocol 1478912) and was approved by the Ethics Committee of the UFERSA (Protocol 23091.001975/10-24).

\section{Biometric data and gross morphology}

The specimens were measured using a caliper in order to obtain the "crown-rump - CR" (EVANS \& SACK 1973). With the use of a digital scale (0.001 grams - MARTE) it the weight (g) was determined before fixation of the animals. Fetuses were allocated into 3 Groups (Group I, II, and III), according to their $\mathrm{CR}$ and external features. The nomenclature used was based on International Committee on Veterinary Gross Anatomical
Nomenclature, International Committee on Veterinary Histological and Embryologica Nomenclatura, 2012.

Histology

Samples of lungs were dehydrated in increasing concentrations of ethanols (70 to $100 \%$ ), for 1 hour in each, followed by diaphanization in xylene, for 2 hours and then, samples were embedded in paraffin (Histosecâ - MERCK, lote K91225309). Sections of $5 \mu \mathrm{m}$ were obtained in an automatic microtome (Leica, RM2165) and stained with hematoxylin and eosin - HE and Masson trichrome. The material was analyzed using a light microscope (Olympus BX40, Zeiss KS400).

\section{Immunohistochemistry}

Primary antibody were applied for PCNA (PC10, sc-56, dilution 1:100, Santa Cruz Biotechnology, Santa Cruz, CA, USA), in order to verify cellular proliferation; Oct-4 (sc-4420, dilution 1:100, Santa Cruz Biotechnology, Inc, Europe), to identify pluripotent cells, and VEGF (ab1316, diluição $1: 100$, Cambridge, UK) to proliferation of blood vessels. For that, it was followed a formal protocol (OLIVEIRA et al., 2012). Negative controls was performed using IgG (Goat anti-Mouse IgG - AP 308F, Chemical International).

\section{Scanning electron microscopy (SEM)}

One sample from each Group fixed in $2.5 \%$ glutaraldehyde in $0.1 \mathrm{M}$ buffer, $\mathrm{pH} 7.4$, and postfixed in osmium tetroxide $1 \%\left(\mathrm{SEM}^{\circledR}\right.$, Hatfield, Pennsylvania, PA) were dehydrated in increasing concentrations of etanol (70-100\%) and dried in a critical point dryer (Balzers Union ${ }^{\circledR}$ CPD 020, Liechtenstein, Germany). Then, the material was placed in stubs and covered with gold in a sputter coater (Emitech ${ }^{\circledR}$ K550, Ashford, Kent, England), and were analyzed using a SEM (ME Leo 435 VPZeiss, England).

\section{RESULTS}

General characteristics

The main external features of Group I (days 33-35) were: pigmented retina, forelimb and hind limb enlarged with separated digits, rounded cephalic and occipital regions, short external ear, and short tail. Group II (days 38-40) showed: pronunced external ear and nasal region, and increased size of the whole body regions. Finally, Group III (days 43-45) showed as main characteristics the upper and lower eyelids, keratinized claws, pigmented skin, sensorial 
hair in the nasal region, and complete developed external ear (Figure 1A).

Gross morphology and scanning electron microscopy (SEM)

There were no significant differences on lung morphology among the 3 groups. It was noted only a simple difference in the size of the whole organ size when compared the fetuses of different groups. Externally, the lungs were divided by pronounced fissures on both sides, right and left, corresponding to the divisions of the lobes. Regarding to the lobation, it was identified on the right side the following lobes: right cranial lobe, middle lobe, right caudal lobe, and accessory lobe. On the left side, the left cranial lobe was divided into cranial and caudal segments through the cranial intralobar fissure, and caudal lobe as observed in the gross morphology analysis and SEM (Figures 1B-1D).

The trachea was composed of hyaline cartilage rings and connective tissue (Figures 1D and $1 \mathrm{E}$ ). It was observed that the primary right and left bronchi arise from the bifurcation of the trachea, immediately dorsal to the base of the heart. Then, the bronchi give rise to the lobar bronchi, which continue to branch to form the bronchial tree.

Histology and immunohistochemistry

In the Group I, the initial development of the bronchi and bronchioles was observed in the lung parenchyma, which were surrounded by abundant fetal mesenchyme and blood vessels (Figures 2A2C), typical characteristics of the pseudoglandular stage. The developing bronchioles had a cubic simple epithelium, with globular cells with rounded nuclei located in the basal region of the cytoplasm. These epithelial cells were supported by a layer of flat cells which maintained contact with the fetal mesenchyme and blood vessels (Figure 2C).

In Group II was observed an increased amount of the number and caliber of the bronchi and bronchioles (Figures 2D and 2E), decreased mesenchyme and the initial opening of the internal lumen of the bronchioles (Figure 2F). In Group II, the number of bronchi and bronchioles and the lung reached the canalicular stage gradually increased (Figure 2D).

Lungs of Group III were completelly developed. Inside the lung parenchyma, bronchi were composed by prismatic epithelium surrounded by cartilage hyaline (Figures $2 \mathrm{G}$ and $2 \mathrm{H}$ ). During the maturation of the lung, the parenchyma in this phase was composed of alveolar cells, thereby reaching the alveolar phase. With the rapid cell differentiation, a larger bronchial lumen was observed (Figure 2I), with early development of alveoli.

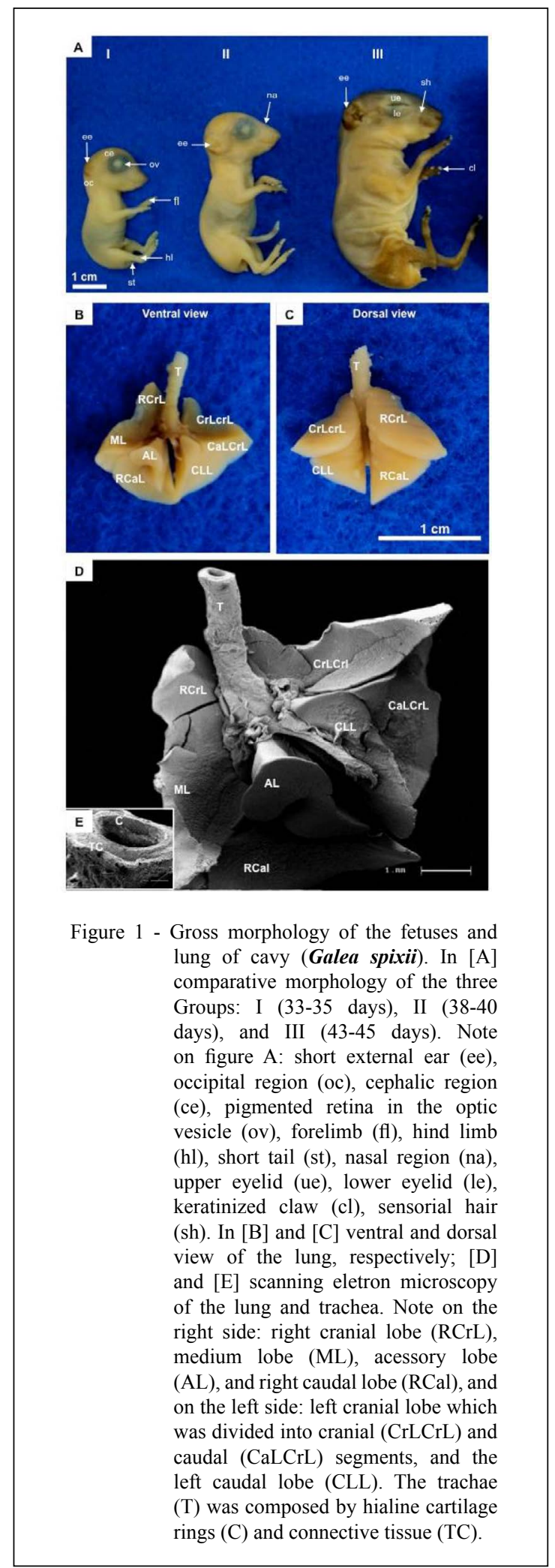

Ciência Rural, v.46, n.9, set, 2016. 


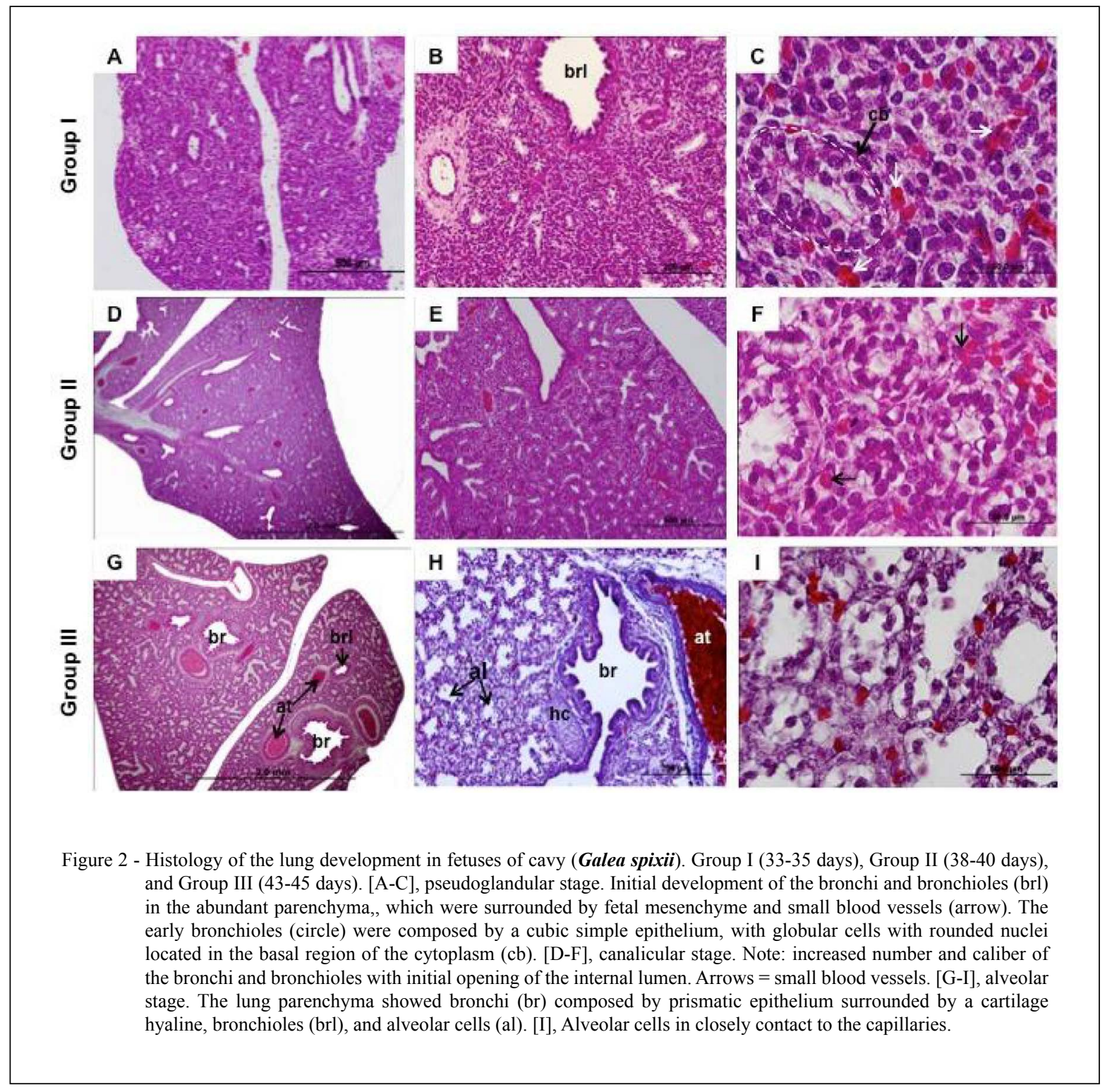

Both, Group I and II showed similarities in regarding to the expression of PCNA, VEGF, and Oct- 4 markers. In contrast, the samples from Group III were negative for all markers. Thus, throughout early pregnancy it was observed an intense proliferative activity on epithelial cells lining the bronchi and bronchioles, hialine cartilage, and mesenchyme on Groups I and II, as demonstrated on figure $3 \mathrm{~A}$ for the Group I. In the same regions there was no labbeling for Group III (Figure 3B). It was observed the expression of VEGF in the epithelial region of the bronchi, bronchioles, and mesenchyme in the Groups I and II (Figure 3C), and its absence of expression on Group III (Figure 3D). In relation to the presence of pluripotent cells, it was verified the co-location of these Oct-4+ cells with those who were on proliferative phase, especially in the epithelial bronchi and bronchioles, and also on alveolar cells of the Groups I and II (Figure 3E). In contrast, it was not identified Oct-4+ cells in the Group III (Figure 3F).

\section{DISCUSSION}

Currently, the most common experimental models used for the study of acute and chronic lung diseases are represented by small rodents and mini pigs, due to the easy and practical management of these animals in animal facilities and low costs (CABRAL, 2013). However, there is a constant search for new animal species that may present, at

Ciência Rural, v.46, n.9, set, 2016. 


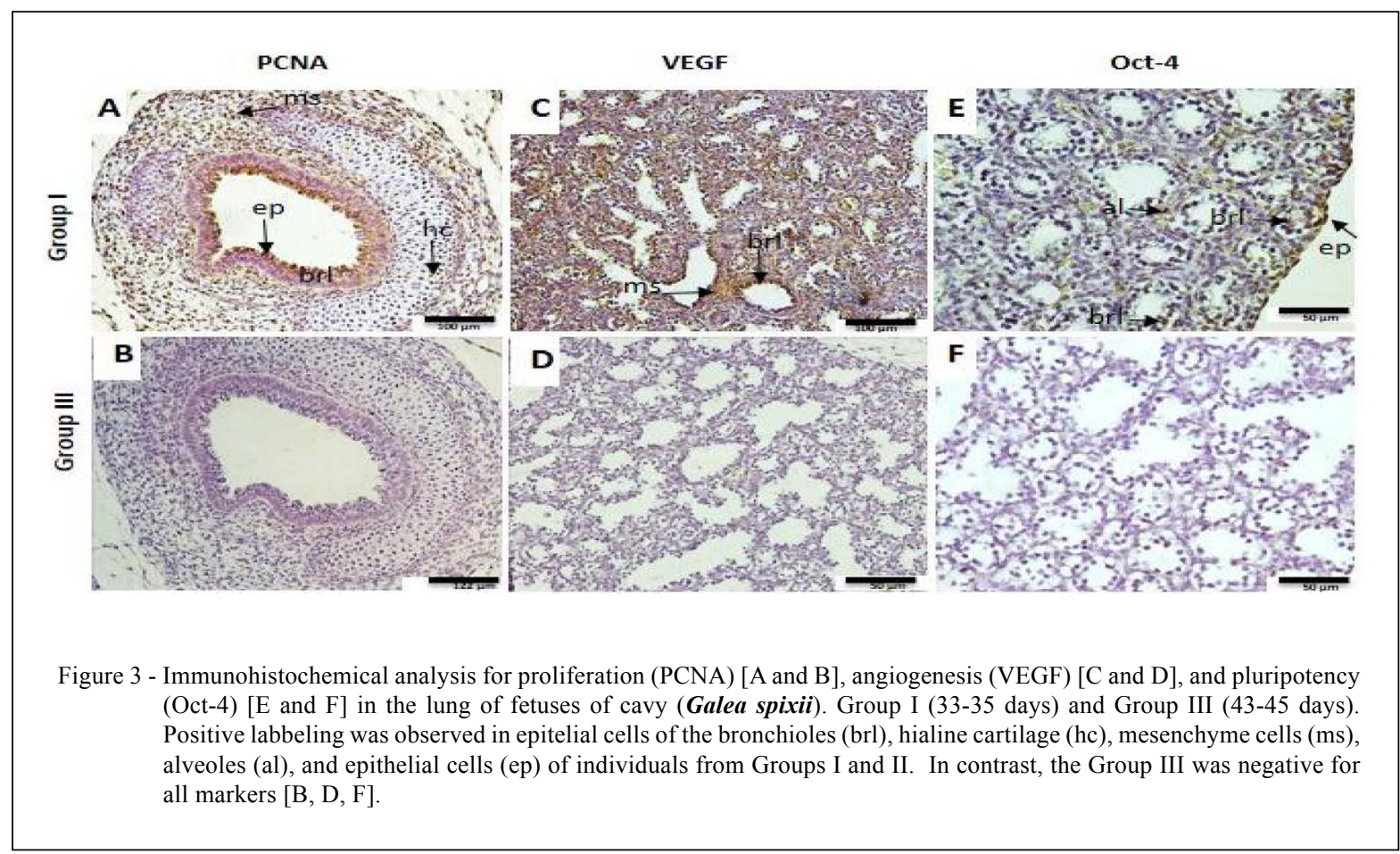

different levels, homology with humans, in order to elucidate events related to the development and physiology of various organic systems. Thus, herein it was characterized the development and maturation of the lung in the cavy by morphology and expression of markers involved in cellular proliferation, vascular growth, and identification of pluripotent cells.

The cavy possessed four lobes in the right lung, similar to that described on literature for other rodents, such as paca (Agouti paca) (REHDER et al., 2008), guinea pig (Cavia porcellus) (COOPER \& SHILLER, 1975), nutria (Myocastor coypus) (MACHADO et al., 2003), and in contrast to what was observed in capybara (Hydrochaeris hydrocaeris), which has the accessory lobe divided into cranial and caudal portions (CITRÂNGULO et al., 2001).

Referring to the lobes of the left lung, the results differed from that observed in the rat, which has only one lobe in the left lung without cranial and accessory lobes (GREENE, 1955) and for guinea pig (COOPER \& SHILLER, 1975), nutria (MACHADO et al., 2003), and paca (REHDER et al., 2008), which had three lobes in the left lung. However, it was similar to what is known for rabbit (BARONE, 1997), capybara (CITRÂNGULO et al., 2001), agouti (PENNO et al., 2005), and chinchilla (PEREIRA et al., 2005), which showed only two lobes in the left lung, with subdivion of the left cranial lobe into cranial and caudal portions.
With regard to the lung development pattern, this is described in several species of mammals, although times of development of each phase are significantly different among the species, especially due to the period of gestation and the relative degree of lung maturation at birth (PINKERTON \& JOAD, 2000). According to PINKERTON \& JOAD (2000), the pseudoglandular phase in humans is the most critical stage for the development of the conductive portions. In the cavy, the pseudoglandular phase was associated with the development of the bronchi and bronchioles with a simple cuboid epithelium, as described for mice (WARBURTON et al., 2010). This is different to the morphological descriptions of the bronchi and bronchioles epithelium in humans, for which a columnar epithelium is characteristic (PINKERTON \& JOAD, 2000). According to ELHAFEZ (2012), the canalicular stage is an important step in the development of the rabbit lung, since the terminal bronchioles branches into 2-4 acinar channels, from which some cells of the epithelium line these channels and differentiate into type I pneumocytes. In the descriptions for Group II, the most remarkable features were: increased number of bronchi and bronchioles, division of the lung in lobes and decreased amount of mesenchyme. Moreover, results showed a progressive decreased expression of markers involved in cell proliferation (PCNA), angiogenesis (VEGF) and pluripotency

Ciência Rural, v.46, n.9, set, 2016. 
(Oct-4) during pregnancy. Recent results showed the importance of these markers for differentiation processes, morphogenesis and lung growth (PINKERTON \& JOAD, 2000). The decreased expression of these markers during gestation can be explained by the decrease of proliferative activity of the cells directly before birth. It is known that the vascular endothelium growth factor (VEGF) is highly expressed in epithelial cells located near to microvascularization tissue (BERSE et al., 1992). Indeed, it was observed an intense staining for VEGF in the lung parenchyma, which is richly vascularized. In regard to the Oct-4, which was expressed in the lung of the cavy in Groups I and II, it representes a marker expressed by pluripotent cells and its expression in cell and tissue cultures is related to cell differentiation (PALMIERI et al., 1994). In addition, it plays an important role in self-renewal of somatic stem cells and maintenance of tissue homeostasis (WU \& SCHOLER, 2014), This indicates that the early stages of development of the cavy lung shows undifferentiated cells with high capacity of differentiation.

In most mammals with short gestation periods, such as rodents and lagomorphs, the birth occurs before the formation and maturaration of the alveoli in the lungs, so, in these species the alveolarization can be considered late and/or an postnatal event (PINKERTON \& JOAD, 2000). However, the cavy development pattern differs from other rodents, since the alveolar period occurs earlier when compared to other rodents and lagomorphs.

Finally, an important feature of the development of the cavy lung is that they are born in the alveolar stage, as well as in humans, whereas rats and mice are born in the saccular stage (SCHITTNY, 2007), allowing infer that the cavy can be used as an experimental model for understaing the development of early respiratory diseases in humans.

\section{CONCLUSION}

Among the variety of mammalian species for which lung embryology is known, the cavy ( $\boldsymbol{G}$. spixii) showed more similarity with human fetuses than other rodent species even from the same systematic group, especially because they born in the alveolar stage. It was demonstrated that there is a high intensity markers expression involved in cell proliferation, angiogenesis and pluripotency in the earliest stages of development, showing that these cells have a high capacity for proliferation and pluripotency, suggesting its use in future studies, mainly related to the establishment of cell cultures for regenerative medicine.

\section{ACKNOWLEDGEMENTS}

We would like to thank Dr. Rose Eli Rici for technical support. Financial support was provided by Fundação de Amparo à Pesquisa do Estado de São Paulo (FAPESP) (Process 2012/51864-2).

\section{REFERENCES}

BALAZS, G et al. Bleomycin- induced fibrosis in pigs: Evaluation with CT. Radiology, v.191, p.269-272, 1994. Available from: $<$ http://www.ncbi.nlm.nih.gov/pubmed/7510895>. Accessed: Sept. 30, 2015. doi: 10.1148/radiology.191.1.7510895.

BARONE, R. Anatomic comparée des mamifères domestiques. Paris: Éditions Vigot, 1997. 904p.

BERSE, B. et al. Vascular permeability factor (vascular endothelial growth factor) gene is expressed differentially in normal tissues, macrophages, and tumors. Molecular Biology of the Cell, v.3, p.211-220, 1992. Available from: <http://www.ncbi.nlm.nih.gov/ pmc/articles/PMC275520/>. Accessed: Sept. 30, 2015.

CABRAL, R.M. Modelos experimentais de doenças pulomonares fibrosantes. Pulmão RJ, v.22, p.10-13, 2013. Available from: $<$ htpp://sopterj.com.br/profissionais/_revits/2013/n_01/04pdf $>$. Accessed: Mar. 20, 2015.

CITRÂNGULO, M. et al. Lobation and Arterial vascularization of the lung of capybara (Hydrochaeris hydrocaeris). Arquivos de Ciências Veterinárias e Zoologia da UNIPAR, v.4, n.2, p.119-127, 2001. Available from: <http://bases.bireme.br/cgi-bin/ wxislind.exe/iah/online/?IsisScript $=\mathrm{iah} / \mathrm{iah} . \mathrm{xis} \&$ src $=$ google $\&$ base $=$ LILACS\&lang $=$ p\&nextAction $=1$ nk\&exprSearch=306394\&index Search=ID $>$. Accessed: Mar. 20, 2015.

COOPER, G.; SCHILLER, A.L. Anatomy of the guinea pig. Massachussetts: Harvard University, 1975. 392p.

GREENE, E.C. The anatomy of the rat. New York: Hafner Publishing, 1955. 370p.

ELHAFEZ, E.A.A. et al. Development of the respiratory acinus in the rabbit lung. Recent Researches in Medicine and Medical Chemistry, v.01 p.14-17, 2012. Available from: <http:// www.wseas.us/e-library/conferences/2012/Kos/MEDICAL/ MEDICAL-12.pdf>. Accessed: Mar. 20, 2015.

EVANS, H.E.; SACK, W.O. Prenatal development of domestic and laboratory mammals: growth curves, external features and selected references. Anatomia, Histologia, Embryologia, v.2, p.11-45, 1973. Available from: <http://onlinelibrary.wiley.com/ doi/10.1111/j.1439-0264.1973.tb00253.x/abstract>. Accessed: Mar. 20, 2015. doi: 10.1111/j.1439-0264.1973.tb00253.x.

JUNQUEIRA, L.C.; CARNEIRO, J. Histologia básica. Rio de Janeiro: Guanabara Koogan, 2004. 388p.

MACHADO, G.V. et al. Lobação pulmonar e distribuição das artérias pulmonares. Arquivos de Ciências Veterinárias e Zoologia da UNIPAR, v.6, p.168, 2003. 
MCCULlOUGH, B. et al. Bleomycin- induced diffuse interstitial pulmonary fibrosis in baboons. Journal of Clinical Investigation, v.61, p.79-88, 1978. Available from: <http:// www.ncbi.nlm.nih.gov/pubmed/73549>. Accessed: Sept. 30, 2015. doi: 10.1172/JCI108928.

METZGER, R.S. et al. The branching programme of mouse lung development. Nature, v.4535, p.745-750, 2008. Available from: $<$ http://www.nature.com/nature/journal/v453/n7196/abs/nature07005. html >. Accessed: Sept. 30, 2015. doi: 10.1038/nature07005.

MOORE, K.L.; PERSAUD, T.V.N. Embriologia clínica. Rio de Janeiro: Elsevier, 2004. 609p.

OLIVEIRA, M.F. et al. Chorioallantoic and yolk sac placentation in Trichomys laurentinus [Echimydae] and the Evolution of histricognath Rodents. Journal of Experimental Zoology. Part B, Molecular and Developmental Evolution, v.318, p.13-24, 2012. Available from: <http://www.ncbi.nlm. nih.gov/pubmed/21898786>. Accessed: Mar. 20, 2015. doi: 10.1002/jez.b.21428.

PALMIERI, S.L. et al. Transcription factor is differentially expressed in the mouse embryo during establishment of the first two extraembryonic cell lineages involved in implantation. Developmental Biology, v.1, p.259-67, 1994. Available from: $<$ http://www.ncbi.nlm.nih.gov/pubmed/7958450>. Accessed: Sept. 30, 2015. doi: 10.1006/dbio.1994.1312.

PENNO, A.K. et al. Lobação, ramificação brônquica e distribuição arterial no pulmão da cutia (Dasyprocta sp., Mammalia Rodentia). Brazilian Journal of Veterinary Research and Animal Science, v.42, n.5, p.327-332, 2005. Available from: $<$ http://www.revistas.usp. br/bjvras/article/viewFile/26408/28191>. Accessed: Mar. 20, 2015.

PEREIRA, R.Let al. Topologia e topografia do aparelho respiratório e árvore brônquica de Chinchilla lanigera. In: CONGRESSO DE
INICIAÇÃO CIENTÍFICA (UFRGS), 14., 2005, Porto Alegre, RS. Anais... Porto Alegre: UFRGS, 2005. p.401.

PINKERTON, K.E.; JOAD, J.B. The mammalian respiratory system and critical windows of exposure for children's health. Environmental Health Perspectives, v.108, p.457-462, 2000. Available from: $<$ http://www.ncbi.nlm.nih.gov/pmc/articles/ PMC1637815/>. Accessed: Mar. 20, 2015.

REECE, W.O. Respiração nos mamíferos. In: Dukes, fisiologia dos animais domésticos. 12.ed. Rio de Janeiro: Guanabara Koogan, 2006. p.103-133.

REHDER, A.M.A. et al. Lobação, árvore brônquica e vascularização arterial do pulmão da paca (Agouti paca, Linnaeus, 1766). Ciência Animal Brasileira, v.9, p.442-448, 2008. Available from: <http://www.revistas.ufg.br/index.php/vet/article/ download/1102/3722>. Accessed: Sept. 30, 2015.

ROBERTS, C.M.; PERRY, J.S. Hystricomorph embryology. Symposia of the Zoological Society of London, v.34, p.333360,1974

SCHITTNY, J.C.; BURRI, P.H. Development and growth of the lung. Development, v.139, p.111-124, 2007. Available from: $<$ http://www.ana.unibe.ch/users/schittny/public_html/Reprints/ Schittny2008Fishman.pdf>. Accessed: Mar. 20, 2015.

WARBURTON, D. et al. Lung organogenesis. Current Topics in Developmental Biology, v.90, p.73-150, 2010. Available from: $<$ http://www.ncbi.nlm.nih.gov/pmc/articles/PMC3340128/>. Accessed: Sept. 30, 2015. doi: 10.1016/S0070-2153(10)90003-3.

WU, G.; SCOLER, H.R. Role of Oct-4 in the early embryo development. Cell Regeneration, v.3, p.2-10, 2014. Available from: $<$ http://www.cellregenerationjournal.com/content/3/1/7> . Accessed: Sept. 30, 2015. doi: 10.1186/2045-9769-3-7. 